\title{
INCREASING AUDIENCE: ENGAGING WITH BIG DATA \& AI \& IOT \& MR - REAL INTERACTIVITY (DEMO CHATBOT)
}

\section{Chair: Rodrigo Dias Arnaut - Director - EraTransmidia/ FAAP/ SET/ Esconderijo}

In the 1990s the great label of creativity was Research and Development (R \&amp; D), in 2000 we started to call it "Innovation" and in this decade the concept of "Disruptive Innovation" is geting stronger.Of an outdated and old model to be replaced by a new and contemporary model, a rupture of concepts, bringing disruption as the "beyond" of the new, an interruption of the normal course of a process. Given this scenario of new labels, we will translate in a practical way what BigData means, where large volumes of different information are quickly accessed, as well as Al (Artificial Intelligence) where algorithms and tools are increasingly present in our day-to-day life, in complex software or even in our social media chats. Other alphabet soup are Virtual Reality (VR), AR (Augmented Reality) and MR (Mixed Reality), which lead users to interact with virtual environments increasingly common in brand experiences, and loT (Internet Of Things) that will reach more than 50 billion connected devices in the internet in 2020, involving the whole chain of the consumer industry. With all this Disruption, our lives are becoming totally interactive, we talk to machines all the time, and it may be that we will not talk to humans any more. Really? Come listen to what this disruptive folks will present in the debate, bring your friends and come and discuss with us the future of media interaction. We will do a realtime demonstration of the creation and programming of a chatbot within a fanpage, a Facebook messenger robot.

\section{- TALKING WITH MACHINES}

\section{Speaker: Jefferson Prestes - Director Novatrix / Chronos Bot}

Using Al tools to optimize costs, amplify the quality and accuracy of information for consumers, users and viewers through the use of Machine Learning and Al integrated into social media, such as fanpages within Facebook. Cases even from TV stations that release videos through chatbot, an OTT (Over The Top) via Al! 
- MIXED REALITY HAS ARRIVED!

Speaker: Rodrigo Terra - Founder and Director Arvore.io / President EraTransmidia

How MR (Mixed Reality) will transform our world of content and immersive experiences, blending holography with real images. Productions in VR (Virtual Reality), case McDonalds; Applications AR (Augmented Reality) as Pokémon and Transmedia, are state of the art in building brand experiences for the new generation of audience that the media world is facing today.

- ENGAGEMENT AND ONLINE VOTING Speaker: Renato Teixeira - Choicely Brazil / FAAP

Advertising professional is a consultant for market research and media, and digital marketing strategies. Professor of behavior of the television audience at FAAP. With experience in media and market research for 28 years at IBOPE Media and Datafolha institutes.

- HOW THE INTERNET OF THINGS AND BIG DATA WILL CHANGE OUR LIVES AND THE BROADCAST WORLD

\section{Speaker: Marcelo Blum - Videodata Systems and Technology Manager}

The new generations are accustomed to "all at the same time now". We live in a world in which things grow exponentially and paradigms are constantly broken. Consolidated businesses disappear and new businesses come up quickly, changing habits and making people's lives easier. The media and entertainment industry needs more and more to incorporate these concepts, to become more efficient, profitable and therefore keeping itself relevant. The internet of things will revolutionize homes and businesses in general, interconnecting devices, social networks, automating processes and at the same time generating an enormous mass of data, which through Big Data tools, can anticipate the yearnings of people. The contents and advertising will be increasingly transmedia and multiscreen experiences, in which the reactions will be monitored in real time and the experiences adapted to each person.

\section{- CREATING CONTENT USING AUDIENCE DATA}

\section{Speaker: Robson Ferri - Radio and Advertising Professional}

Creating content for radio shows is a challenge, especially for diversified audience segmentation. We have almost 10,000 educational, commercial and community TV and radio stations throughout the country, 4377 community radios and 1501 FM radios. Analyzing audience data and getting to know the target audience of these radios is essential in the content production strategy. Conducting research and using interactivity with bigdata and engagement technologies can transform content creation into the starter engine of the broadcaster, increasing or even decreasing audience leakage for other media. 


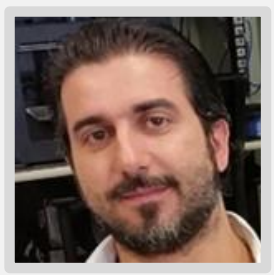

\section{Rodrigo Dias Arnaut - Director - EraTransmidia/ FAAP/ SET/ Esconderijo}

Transmedia consultant and planner for producers and agencies, by Esconderijo das Crianças, digital media professor at FAAP in communications courses, undergraduation and pos graduation. Master of Science from USP (Poli), specialization on Business Management and Technological Innovation at ESPM, Computer Engineer at USJT. Concluded an extension course in E-business in UofT (University of Toronto). President at EraTransmidia Association, where he currently develops audiovisual production research in the field of immersive video, virtual reality / augmented and actions of social impact. With 25 years of professional and academic experience in Technology, Business and Communication in brainstorming and Transmedia projects, IT, Telecom, TV, IoT, Mobile, Web, Games, Wearables, Interactivity, Holography, Virtual and Augmented Reality, Media , Advertising and marketing, 21 years in the Globo group at R\&D Research and Development for technology to Sports areas, Journalism and Entertainment, where he developed more than 50 projects received 15 awards, highlighting IBC Special Awards of the "float" (Amsterdam). It is also a partner at startup Gigamobb and consulting at Esconderijo das Criancas, focused on developing projects with MAMP methodology (Multi Platform Multi Audience) created by EraTransmídia. Vice Director of Pay TV and New Media at SET. Speaker at over 200 events in Brazil and abroad.

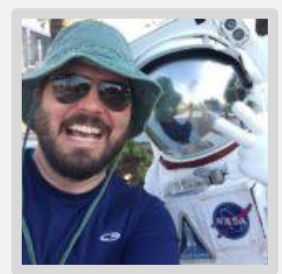

\section{Jefferson Prestes - Director Novatrix / Chronos Bot}

Jeff is Entrepreneur and a Polymath Developer, from C to Go he has worked with many different technologies during his 21 year career including Business Intelligence, e-commerce and web development. Internet of Things, Physical Web and Machine Learning are his new passions. As a specialist and researcher, he creates new technology uses for the future that combines mobile, server technologies and electronics to build Cognitive Computing.

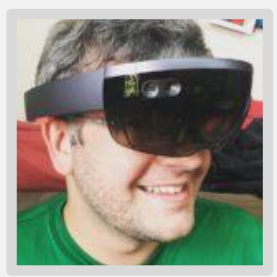

\section{Rodrigo Terra - Founder and Director - Arvore.io / President EraTransmidia}

Post-Graduate in Administration by FGV. Specialist in Entrepreneurship by IBMEC-SP. Graduated in Radio and TV by FAAP-SP. He studies and develops Transmedia content since 2006. He has directed and conducted several projects in audiovisual and transmedia for broadcasters and producers. He was co-author, director-general and artistic director of the series Sexo no Sofá, screened by TV Futura and Glitz * (Turner). Consultant in Transmídia in the program Objetiva Audiovisual of Sebrae/APRO, professor of Content Production in Audiovisual module at PUC-PR. $\mathrm{He}$ is creative director and evangelist of immersive experiences, Virtual Reality, Augmented and Mixed. Today he is president of the EraTransmidia Association, partner-director of Fazenda Urbana and $\mathrm{COO}$ of Arvore Experiências Imersivas.

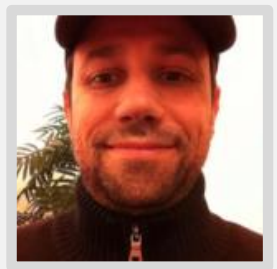

\section{Renato Teixeira - Choicely Brazil / FAAP}

Advertising professional is a consultant for market research and media, and digital marketing strategies. Professor of behavior of the television audience at FAAP. With experience in media and market research for 28 years at IBOPE Media and Datafolha institutes. 


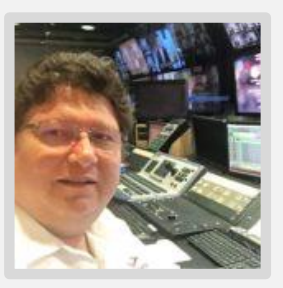

\section{Marcelo Blum - Videodata Systems and Technology Manager}

Graduated in Electronic Engineering from UFRJ, with 25 years of experience in the market of Television Engineering, Videodata Systems and Technology Manager, specialized in Playout Systems, Cloud Playout, Media Asset Management, Video and Media Workflows Orchestration, Video Compression and Transport, Production and Post Production and Critical Mission Systems. Member of SET for more than 24 years, has contributed presenting numerous lectures in its events.

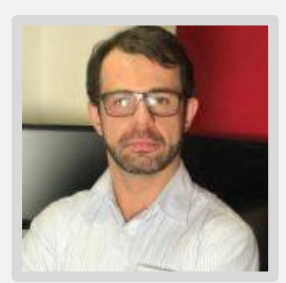

\section{Robson Ferri - Radio and Advertising Professional}

